\title{
THE AMERICAN SOCIETY OF INTERNATIONAL LAW
}

\section{is on the Web!}

\section{http://www.asil.org}

Just in time for its 90th Anniversary, the American Society of International Law announces the arrival of the ASIL World Wide Web Home Page!

You'll find information on Society meetings, publications, activities, membership, and a convenient ASIL Library "Springboard" to other Web sites of interest to the international lawyer. 


\section{THE BEST IN LAW}

\section{International Law Reports}

Consolidated Tables of Cases and Treaties and Indexes-Volumes 81-100

\section{E. Lauterpacht and}

C.J. Greenwood, Editors

Prepared by M.E. MacGlashan

These Reports are an absolutely essential work of reference for all those who rely on the regular reporting of national and international decisions and awards bearing upon international law. This consolidation of Treaties, Cases and Indexes for the most recent 20 volumes assists greatly in making these important materials readily accessible. 56229-5 Hardback about $\$ 190.00$

\section{International Law Reports}

E. Lauterpacht and

C.J. Greenwood, Editors

Volume 102

$55199-4$ Hardback $\$ 135.00$

Volume 101

49648-9 Hardback \$135.00

\section{Fifty Years of the International Court of \\ Justice}

Essays in Honour of Sir Robert Jennings

\section{Vaughan Lowe and}

Malgosia Fitzmaurice, Editors

This text draws together the reflections of the most eminent international judges, practitioners and academics in the field of public international law, on the way that the Court has handled the matters put before it.

Contributors: Georges Abi-Saab, Philip Allott, Geoffrey Marston, Maurice Mendelson, Judge M. Shahabuddeen, Sir Ian Sinclair, Prosper Weil, E.W. Vierdag, Francesco Francioni, D.W. Bowett, C.F. Amerasinghe, Hazel Fox, Harry Post, Barbara Kwiatkowska, Malgosia Fitzmaurice, Sami Shubber, Judge Stephen M. Schwebel, Antonio Cassese, John Collier, Christopher Greenwood, H.W.A. Thirlway, Shabtai Rosenne, Sir Arthur Watts, Gaetano Arangio-Ruiz, E. Lauterpacht, (the late) Judge Ruda, Eduardo Valencia-Ospina, Gillian White, Judge Shigeru Oda, Ian Brownlie, Rosalyn Higgins, James Crawford, Krzysztof Skubiszewski

55093-9 Hardback \$110.00
Precedent in the

\section{World Court}

\section{Mohamed Shahabuddeen}

Although precedent in the International Court of Justice is not binding, the Court relies upon its previous judgments as authoritative expressions of its views. Judge Shahabuddeen shows the extent to which the Court is guided by previous decisions, and how parties to cases themselves use the Court's decisions when framing and presenting their cases.

Hersch Lauterpacht Memorial Lectures 12

56310-0 Hardback about $\$ 54.95$

\section{The Haiti Crisis in International Law Marc Weller, Editor} Ana MacLean, Assistant Editor

The Haiti episode represents the first and only instance of a UN-mandated military operation to restore democracy, against the wishes of an effective government in the target state. This volume documents the crisis from the initial coup, the immediate responses of the UN, the Organization of American States (OAS), Human Rights bodies and states involved in the crisis.

Cambridge International Documents Series 10 55048-3 Hardback about $\$ 150.00$

\section{The Control and} Monitoring of Iraqi Weaponry of Mass Destruction Marc Weller, Editor

Philip Hatfield, Assistant Editor

After the Gulf War, unprecedented calls for the destruction and monitoring of its chemical, biological, nuclear and other convention weapons facilities were leveled against Iraq. The texts of Iraq's commitments to nuclear nonproliferation, materials on the work of UN Special Commission for disarming and monitoring Iraq, and International Atomic Agency documents are reproduced, with a helpful introduction.

Cambridge International Documents Series 11 55047-5 Hardback about $\$ 150.00$ 


\section{New Resources for International Law}

\section{UNEP's New Way Forward: Environmental Law and Sustainable Development}

"A timely contribution to address the challenges of sustainable development through progressive development and effective implementation of the principles of environmental law."

Issued as a contribution towards the Fiftieth Anniversary of the United Nations, this book offers a compilation of articles written by legal experts. It discusses such subjects as: environmental equity and international law; avoidance, prevention and settlement of environmental disputes; liability for environmental damage; human rights, environment and development and foreign investment and environmental law. Also presented, is a special article on -

International Law as a Language for International Relations. This book's wealth of information, which is based on sound theory and practice, is a reservoir of ideas.

E.96.III.D.97 $\quad \mathbf{9 2 - 8 0 8 - 1 5 2 4 - 0} \quad 397$ pp. $\quad \$ \$ 80.00$

\section{Public International Law: A Select Bibliography}

This Bibliography is an invaluable source of information in the area of public international law and covers the following five selected areas:

- General Principles

- Peaceful Settlement of Disputes between States

- Codification and Progressive Development

- Research and Education

- New Challenges and Expectations

Each topic has been categorized into either books or articles and arranged alphabetically by author or title. A useful 'names index' has been included to facilitate easy search.

E.95.V.8 $92-1-133488-8 \cdot 51$ pp. $\quad \$ 15.00$ 


\section{THE AMERICAN SOCIETY OF INTERNATIONAL LAW \\ "International law has become central to community concerns." -ASIL President Edith Brown Weiss \\ It has become vital, not only to influential policymakers, leading academics, government officials, and diplomats, but to attorneys, corporate decision makers, students, and jurists located in towns large and small, across the country and throughout the world. \\ Benefits and Opportunities}

The ASIL informs members through news an studies ... involves members through conferences, meetings, and research groups ... and helps members who have similar interests meet each other and work together through local networks and issue-specific groups.

\section{Interest Groups}

-Human Rights -Intl Economic Law Intl Space Law Intl Environmental Law -Dispute Resolution in Intl Commercial Contracts - Young Members Antarctic Law, Politics and Resource Policy Arms Control and Nonproliferation Intl Criminal Law -Intl Legal Theory Intl Organizations - Law in the Pacific Region Lieber Society on the Law of Armed Conflict - Private Intl Law $\square$ Rights of Indigenous Peoples $\square$ Southern Africa - Status of Minorities and Other Communities $\mathbf{U}$ U.N. Decade of Intl Law Wildlife Law -Women in Intl Law Intellectual Property Law

Membership includes a subscription to the premier quarterly, American Journal of International Law as well as the ASIL Newsletter. The ASIL extends its membership to individuals whose activities or interests involve international law. Your membership is welcomed. Decide now to join the ASIL, your gateway to greater impact and effectiveness in today's world.

2223 Massachusetts Avenue, N.W. • Washington, D.C. 20008-2864

202-939-6000 • FAX 202-797-7133

\section{In today's world, international law matters ... to everyone.}




\title{
International Law Directory
}

\author{
- Need to locate a colleague? \\ - Contact someone with a particular \\ international law interest?
}

Explore the 1995-1996 ASIL Membership Directory!

The Society's 4,300 members are interested and involved in all branches of the discipline. The Directory allows you to reach these individuals quickly by providing addresses, telephone and fax numbers, and even e-mail addresses when applicable. Separate geographical and professional indexes, as well as full ASIL Interest Group listings, make the Directory even more versatile and useful. Only a limited number have been published - order your copy today!

YES! Please send me copies of the 1995-1996 ASIL Membership Directory

$\$ 40$ (ASIL member price) $\square \$ 70$ (Non-member price)

Directory Amount:

Postage/Handling (20\%):

Total Amount:

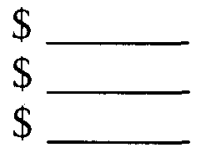

$\square$ Check enclosed (payable to ASIL) $\square$ Visa $\square$ MasterCard Signature

Card No. Exp. Date

Shipping Address (please print or attach a business card):

The AMERICAN Society OF INTERNATIONAL LAW 2223 Massachusetts Avenue NW — Washington DC 20008-2864 Phone: 202-939-6000 $~$ Fax: 202-797-7133 


\section{Important International Law Titles from...}

\section{THE PROBLEM OF REFUGEES IN THE LIGHT OF CONTEMPORARY INTERNATIONAL LAW ISSUES \\ edited by Vera Gowlland-Debbas}

The contributions collected in the present book go beyond refugee law in its traditional sense, largely centred on questions of durable asylum and the plight of only a small tranche of the asylum-seeking population, in situating refugee law within the broader international legal system.

1995. Softcover, ISBN 90-411-0085-7, $\$ 70.00$

\section{CHILDREN ON THE MOVE}

How to Implement Their Right to Family Life

edited by Jaap Doek, Hans van Loon, and Paul Vlaardingerbroek

Children on the Move provides the reader with an in-depth analysis of the various legal aspects (problems and remedies) of inter-country adoption, international child abduction, and children as international refugees.

\section{Hardcover, ISBN 90-411-0156-X,}

$\$ 122.00$

\section{TRANSFRONTIER MOBILITY OF LAW} edited by A.J. de Roo, Robert W. Jagtenberg, Esin Örücü

This volume is a collection of the papers presented on a study day 'Transfrontier Mobility of Law' held in Erasmus University, Rotterdam, on 23 September 1994. All these papers help the reader to see how the problems associated with the transfrontier mobility of law are universal, how very interesting such movements are - not just in historical terms, but in the making - and how there is indeed a universal need for a wider analytical framework to assess future developments.

1996. Softcover, ISBN 90-411-0170-5, $\$ 42.00$
EMERGING ELECTRONIC HIGHWAYS New Challenges for Politics and Law edited by Victor J.J.M. Bekkers, Sjaak Nouwt, Bert-Jaap Koops

Electronic highways are emerging; the information society is in the making, but who is building the infrastructure, and whose interests are to be taken into account in establishing the electronic superhighway? This book sets out important administrative and legal implications for political scientists, lawyers, as well as other professionals working on electronic highways.

1996. Hardcover, ISBN 90-411-0183-7, $\$ 87.50$

\section{ECONOMIC DEVELOPMENT, FOR-} EIGN INVESTMENT AND THE LAW Promoting Economic Development through Private Sector Involvement, Foreign Investment and the Rule of Law edited by Robert Pritchard

Practising lawyers from all over the world have contributed to this book with their knowledge and expertise. The issues involved in the economic development process have been pursued with a practical approach. This book will serve as a source of practical information for a wide range of people interested in the legal aspects of development and investment issues.

1996. Hardcover, ISBN 90-411-0891-2

$\$ 102.00$

\section{EVOLVING CONSTITUTIONS OF INTERNATIONAL ORGANIZATIONS by Tetsuo Sato}

This book analyzes the law-creating process relating to the interpretation of constituent instruments of international organizations. This topic is one of the key issues concerning the structures and activities of international organizations.

1996. Clotb, ISBN 90-411-0202-7, $\$ 120.00$

\section{KLuWer LAW INTERNATIONAL}

Call Toll-Free in the United States: 1-800-577-8118 


\section{KLUWER LAW INTERNATIONAL}

\section{THE AFRICAN \\ COMMISSION ON \\ HUMAN AND \\ PEOPLES' RIGHTS \\ by Evelyn A. Ankumab}

This study is a description and analysis of the work of the African Commission on Human and People's Rights. Its aim is to make the African Commission accessible, and therefore emphasizes the practical rather than the theoretical aspects of the work of the Commission.

\section{Softcover, ISBN 90-411-0130-6, $\$ 80.00$}

\section{WEAPONS PROLIFERATION AND WORLD ORDER: After the Cold War by Brad Roberts}

With the end of the Cold War, the subject of weapons proliferation has acquired new interest and prominence. This study describes the prevailing conceptual model of nuclear proliferation, evaluates proliferation's changing technical features, considers economic and political factors bearing on its future rate and character, and speculates about proliferation's implications on the post-cold-war world order. It concludes with an assessment of progress to date in meeting these new challenges, arguing that the new agenda is only slowly coming into focus.

\section{Hardcover, ISBN 90-411-0205-1, $\$ 115.00$}

\section{THE EXTINCTION OF NATION}

\section{STATES: $A$ World without Borders} by L. Ali Kban

This work explores whether the nation-state is a useful concept under contemporary international law. It traces the historical development of the nation-state, then argues that due to increased interdependence among the peoples of the world, the nation-state has become dysfunctional in serving the needs of global life. Emphasizing a world free movement of goods, services, capital, information and the peoples of the world.

1996. Cloth, ISBN 90-411-0198-5, $\$ 115.00$

SELF-DETERMINATION, TERRORISM AND THE INTERNATIONAL HUMANITARIAN LAW OF ARMED CONFLICT by E. Chadwick

Since international terrorism was defined by the world community in 1937, a World War and the Cold War have made any such modern consensus impossible. Dr Chadwick argues that the separability of illicit acts of war would enable the international community to reach consensus more easily in regard to a definition of terrorism, and a coordination of efforts to deter its occurrence.

1996. Cloth, ISBN 90-411-0122-5, $\$ 95.00$

\section{INTERNATIONAL ENVIRONMENTAL}

\section{LAW: Multilateral Treaties}

edited by W.E. Burbenne

This is the most comprehensive reference work on environmental treaties available. A regularly updated looseleaf, International Environmental Law: Multilateral Treaties will help ensure that your information on environmental law is kept current. International Environmental Law: Multilateral Treaties consists of seven volumes, amounting to approximately 8000 pages. It gives you access to all the major multilateral agreements, organised in chronological order - and also contains treaties not of a direct environmental nature, but which have environmental implications which must be addressed by the international lawyer.

\section{Looseleaf (8 Volumes),}

ISBN 90-411-0757-6, \$427.00

\section{Massachusetts Avenue • Cambridge, MA 02139}

(617) 354-0140 • FAX (617) 354-8595・ sales@kli.com 


\section{From the International Centre for Settlement of Investment Disputes (ICSID)}

\section{ICSID REVIEW: Foreign Investment Law Journal}

A publication devoted exclusively to foreign investment law. Ibrahim F. I. Shihata, Editor

The journal presents analysis and information on the law and practice of foreign investment in the form of articles, comments, cases, documents, bibliographies and book reviews.

Contributions to a recent issue include:

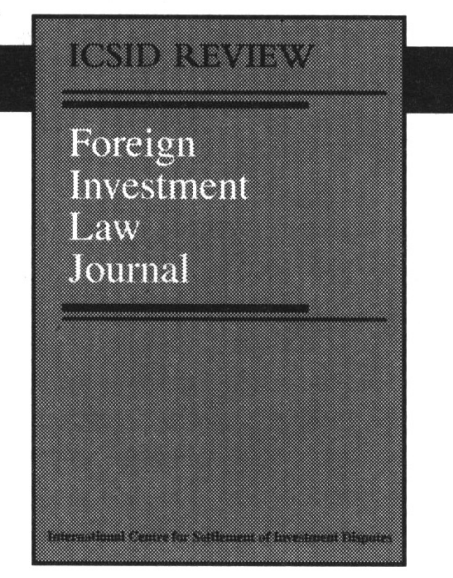

- Towards an International Agreement on Foreign Direct Investment?

- Thirty Years of Lex Mercatoria

- Arbitration Without Privity

Subscription: Regular, $\$ 55$; Special Category, $\$ 27.50$ for persons with a mailing address in a non-member country of the Organisation for Economic Co-operation and Development. Prepayment required. Subscribers in Canada and Mexico add $\$ 4.40$ postage; outside North America, add $\$ 8.00$. Payment must be drawn on a U.S. bank or be by international money order. Maryland residents add $5 \%$ sales tax.

Toll-free number for charge orders only: 1-800-548-1784.

Regular number: 1-410-516-6987

Payment Options:

$\square$ Check or money order enclosed, payable to Johns Hopkins University Press

$\square$ VISA $\square$ MasterCard

Card \# Exp. Date

Name

Signature

Address

City/State/Zip

Send order with payment to: The Johns Hopkins University Press, Journals Publishing

Division, PO Box 19966, Baltimore, MD 21211 


\section{RECENT RELEASES SELECTED INFORMATION MATERIALS

\section{PUBLICATIONS}

\section{CUMULATIVE DIGEST OF UNITED STATES PRACTICE IN INTERNATIONAL LAW 1981-1989. BOOK III.}

Book III, the concluding volume of the Cumulative Digest of United States Practice in International Law, 1981-1988, will become available from the Govemment Printing Office after April 15, 1996.

Book III consists of the second part of Chapter 10, and Chapters 11 through 15. Chapter 10, International Economic Law, contains materials on debt rescheduling, intellectual property, fuels and energy, communications and transportation, labor, and economic sanctions, including sanctions against terrorist-supporting states. Chapter 11, Environmental and Health Affairs, presents materials on transfrontier pollution, including air pollution (in regard to both Canada and Mexico), protection of the ozone layer, transboundary movements of hazardous wastes, whaling; drug control, and AIDS/HIV. Chapter 12, Scientific, Educational and Cultural Affairs, addresses illicit import, export and transfer of cultural property, statutes of limitation and cultural property litigation, international expositions, and Voice of America relay stations.

Chapter 13, Peaceful Settlement of Disputes, is divided into three sections. The first is devoted to the diplomatic processes of negotiation (Kampuchea), conciliation (the Esquipulas Central American Peace Process), and mediation (the Contadora Process), and to the U.S.-Chile disputes treaty (invoked to resolve the claims arising from the 1976 Letelier assassination). The second section, on arbitration, covers important issues addressed by the Iran-United States Claims Tribunal during the period 1981-1988, as well as the resolution of arbitrations between the United States and the Union of Soviet Socialist Republics, regarding construction of their respective Embassies in Moscow and Washington, and between the United States and the United Kingdom, regarding Heathrow Airport user charges. The third section focuses on the International Court of Justice: the modification and subsequent termination of U.S. acceptance of its compulsory jurisdiction, arising from Nicaragua v. United States, and the general issues of jurisdiction and admissibility presented by that case; the obligation to arbitrate under the U.N. Headquarters Agreement; and the promotion of consensual jurisdiction, including discussion of two such cases before Special Chambers that involved the United States: the Gulf of Maine Case and the Raytheon (ELSI) Case.

Chapter 14, Legal Regulation of Use of Force, addresses, inter alia, the military operation in Grenada, self-defense against terrorism, including air strikes against Libya, the laws of war, developments in arms control and disarmament, the War Powers Resolution, and military assistance and sales to Angola.

Finally, Chapter 15, Private International Law, describes activities in the codification of private international law through the Hague Conference on Private International law, the International Institute for the Unification of Private Law (UNIDROIT), the U.N. Commission on International Trade Law (UNCITRAL), and the OAS Inter-American Specialized Conferences on Private International Law (CIDIP). The last section concerns international commercial arbitration, including the Inter-American Convention on Commercial Arbitration and the New York Convention.

Book IIl concludes with a Subject Index and Table of Cases for all three volumes.

Order from: Superintendent of Documents P.O. Box 371954

Pittsburgh, Pa. 15250-7954
Tel. No. 1-202-512-1800

FAX No. 1-202-512-2250

Stock No. 044-000-02451-9

If sent by mail, orders should be accompanied by check or money order for $\$ 48.00$, made payable to the Superintendent of Documents. Remittances from outside the U.S. may be made by international postal money order or by draft on a U.S. bank. Orders by phone or FAX, whether domestic or international, may use credit cards (Mastercard or Visa only). 


\section{The leading professional journals}

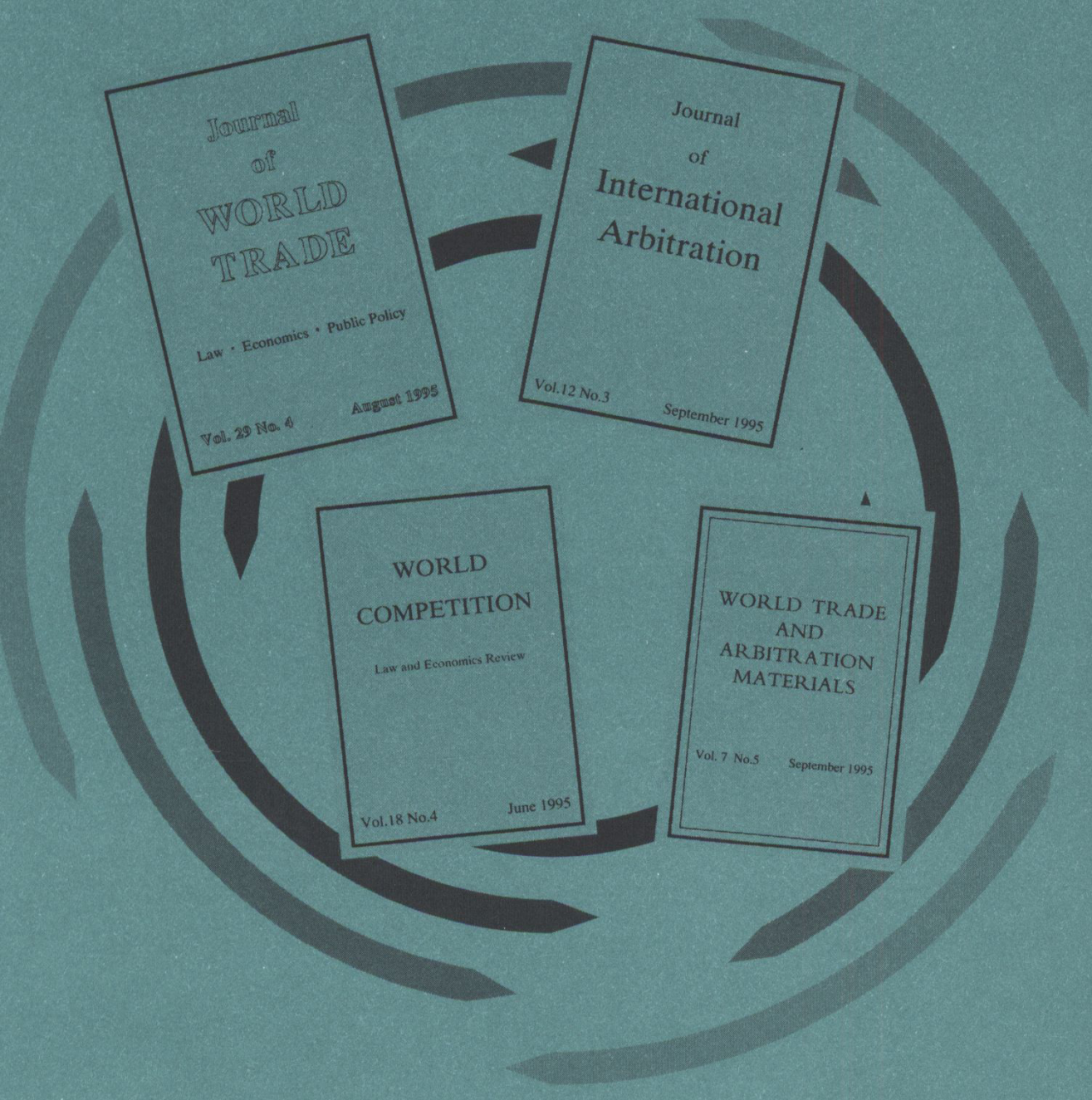

WERNER PUBLISHING COMPANY LTD

P.O. Box 51341211 Geneva 11

Telephone (41-22) 3103422 Telefax (41-22) 3114592 